\title{
Pattern of Traumatic Dental Injuries and associated Risk factors: A Hospital-based Study
}

\author{
Dr. Deepti Shrestha,' Dr. Sumita Upadhyay² \\ 'Assistant Professor, Dept of Conservative Dentistry \& Endodontics, Kathmandu Medical College, Bhaktapur. Nepal \\ ${ }^{2}$ Associate Professor, Dept of Pedodontics, Kathmandu University School of Medical Sciences, Dhulikhel, Nepal
}

Correspondence: Dr. Deepti Shrestha; Email: deeptishrestha@hotmail.com

\section{ABSTRACT}

Introduction: Study of traumatic dental injuries (TDI); a common dental emergencycan facilitate planning of preventive measures, better assessment and carry out treatment effectively.

Objective: To determine the gender and age difference in TDls, etiology, intra-oral soft-tissue and bony injuries, types of tooth fractures and luxation injuries. Also to find out the association between the type of TDI and malocclusion, overjet and lip competency.

Materials \& Method: This cross-sectional study comprised of 121 patients with the history of TDI. Thorough history and clinica examination was done and data were statistically analyzed (confidence interval of $95 \%$ and statistical significance set at $p \leq 0.05)$.

Result: Males were more prone to injuries with a male-to-female ratio of 1.5:1. Fall and road traffic accidents were the most common cause of injuries and males were more prone to injuries due to fall ( $p=0.047)$. The main etiologies of TDIs were fall and RTA in children and adults respectively. Children had more luxation injuries, while adults had more tooth fractures.

Permanent maxillary central incisors were most common to sustain tooth fracture and enamel-dentin fracture were the most common types of injuries.

No statistically significant association was found between overjet and tooth fractures $(p=0.19)$, luxation injuries ( $p=0.24)$, softtissue injuries and bony injuries $(p=0.42)$. Similarly, no significant association was found between lip competency and dental injuries.

Conclusion: Cohort studies must be conducted to associate risk factors and TDIs.

Keywords: dental trauma, overjet, pattern

\section{INTRODUCTION}

The common reasons for dental emergencies are dental trauma (66\%), followed by dental infections, oral bleeding and temporomandibular joint disorders. The incidence of dental trauma has increased during the last 10-20 years and it has been suggested that it will soon exceed that of dental caries and periodontal disease. ${ }^{2}$

Traumatic force to the teeth or periodontium can cause destruction in a variety of directions and of a variety of magnitudes. ${ }^{3}$ Traumatic injuries are classified into various fractures and luxation types, but combination injuries often occur. ${ }^{3}$ Furthermore, these injuries are usually associated with other types of maxillofacial injuries and soft tissue injuries. These injuries may affect quality of life (QoL), psychological problem, pain, loss of function, speech, esthetics and may lead to pulpal necrosis and periapical pathosis.

To prevent traumatic dental injuries (TDIs) and their lifelong consequences; recommendations should be provided for prevention and improvement on quality of life (QOL). For minimizing its sequelae, it would be useful to investigate the pattern of TDIs and risk factors. ${ }^{4}$

The objectives of this study was to determine the pattern of TDls, to assess age and gender difference, etiology, pattern of intra-oral soft tissue and bony injuries, the type and number of teeth injured, the types of tooth fractures and luxation injuries. Also,to find the association between the TDIs andAngle's classification of malocclusion, overjet and lip competency. 


\section{MATERIALS AND METHOD}

This cross-sectional study was conducted in the Dental Department of Dhulikhel Hospital, Kavre from March 2015 to June 2016. This study was approved by the Institutional Review Committee of Kathmandu University School of Medical Sciences. A total of 121 patients with the history of traumatic dental injuries were included in the study which comprised of 153 tooth fractures and 112 luxation injuries. Patients who sustained traumatic dental injuries during the earth quake of April, 2015 were excluded from the study to avoid any bias. After obtaining the written consent from patient or guardian; history was taken and clinical examination was done under dental operating light. The type of soft tissue injury, bony injury, tooth fracture and luxation injury was classified according to Andreason. ${ }^{2}$ Overjet was measured using a graduated periodontal probe. Clinical photographs and radiographs were taken wherever necessary. All demographic and clinical findings were entered in a proforma.

Collected data were entered in SPSS Version 20.0. Descriptive statistical analysis and Chi-square test was done at confidence interval of $95 \%$ at the level of significance set at $p \leq 0.05$.

\section{RESULT}

A total of 121 patients with 265 traumatized teeth were assessed. It was found that, males $(n=74)$ were more prone to injuries than females $(n=47)$ with the male-tofemale ratio of 1.5:1. Fall and road traffic accidents (RTA) were the most common causes of injuries. In RTA cases, females were more prone for TDI than males $(p=0.047)$ (Table 1). Males and females were almost equally prone to tooth fracture with $59.5 \%$ and $61.7 \%$ of occurrence respectively. Females (63.8\%) were more likely to sustain luxation injuries than males (45.9\%), however, it was statistically insignificant ( $p=0.055)$.

Table 2 shows distribution of age group and pattern of injury. The main etiology of TDIs were fall and RTA in children and adults respectively $(p<0.01)$. Table 3 shows distribution of tooth fractures, luxation injury and soft-bony injuries in different age groups. Statistical difference was seen in occurrence of tooth fracture and age group $(p<0.01)$. Among those patients, most common type of injuries were soft tissue injury (43.8\%), bony injury (10.7\%) and combination injury (3.3\%).

Permanent maxillary central incisors (MCl) ( $n=83$, $54.24 \%$ ) were the most common teeth to sustain tooth fracture, followed by permanent maxillary lateral incisors (MLI) ( $n=26,16.9 \%)$. Similarly, permanent $\mathrm{MCl}$ ( $n=38,33.92 \%$ ) were most common to have luxation injury followed by deciduous $\mathrm{MCl}(\mathrm{n}=29,25 \%)$. Out of 147 permanent teeth with tooth fractures, 22 (14.9\%) were posterior teeth. Table 2 shows the distribution of type of tooth fractures and luxation injuries. Table 4 shows the distribution of tooth fractures in permanent and deciduous teeth. Enamel-dentin fracture was the most common in permanent dentition. Concussion and subluxation were the most common types of injuries in permanent and deciduous dentition respectively.

Compared to patients who had trauma with Class I (69\%) and mesial shift (28\%) occlusion, patients with Class II (83\%) and Class III (100\%) were more prone to sustain tooth fractures. No statistically significant association was found between overjet and tooth

Table 1. Etiological factors of TDI

\begin{tabular}{|c|c|c|c|c|}
\hline \multirow{2}{*}{ Etiology } & \multicolumn{2}{|c|}{ Gender } & \multirow{2}{*}{ Total } & \multirow{2}{*}{$p$-Value } \\
\hline & Male & Female & & \\
\hline Fall & $34(28.1 \%)$ & 19 (15.7\%) & $53(43.8 \%)$ & \multirow{5}{*}{0.47} \\
\hline Road traffic accident & $28(23.1 \%)$ & $23(19 \%)$ & $51(42.1 \%)$ & \\
\hline Sports & $10(8.3 \%)$ & $1(0.8 \%)$ & $11(9.1 \%)$ & \\
\hline Assault & $2(1.7 \%)$ & $4(3.3 \%)$ & $6(5 \%)$ & \\
\hline Total & $74(61.2 \%)$ & $47(38.8 \%)$ & $121(100 \%)$ & \\
\hline
\end{tabular}

Table 2. Pattern of injury and age group

\begin{tabular}{|c|c|c|c|c|c|c|}
\hline \multirow{2}{*}{ Age } & \multicolumn{5}{|c|}{ Mechanism of tooth injury } & \multirow{2}{*}{$p$-Value } \\
\hline & Fall & RTA & Sports & Assault & Total & \\
\hline Children & $31(25.6 \%)$ & $0(0 \%)$ & $3(2.5 \%)$ & $1(0.8 \%)$ & $35(28.9 \%)$ & \multirow{4}{*}{$0.01^{*}$} \\
\hline Adolescent & $8(6.6 \%)$ & $10(8.3 \%)$ & $6(5.0 \%)$ & $2(1.7 \%)$ & $26(21.5 \%)$ & \\
\hline Adult & $14(11.6 \%)$ & $41(33.9 \%)$ & $2(1.7 \%)$ & $3(2.5 \%)$ & $60(49.6 .5)$ & \\
\hline Total & $53(43.8 \%)$ & $51(42.1 \%)$ & $11(9.1 \%)$ & $6(5.0 \%)$ & $121(100 \%)$ & \\
\hline
\end{tabular}

*Statistically significant at $p<0.05$ 
Table 3.Ooccurrence of TDls with age group

\begin{tabular}{|c|c|c|c|c|c|c|c|c|}
\hline \multirow{2}{*}{ Age } & \multicolumn{2}{|c|}{ Tooth fracture } & \multicolumn{2}{|c|}{ Luxation injury } & \multicolumn{4}{|c|}{ Soft Tissue/Bony injury } \\
\hline & None & Present & None & Present & None & Soft & Bony & Both \\
\hline Children & 28 & 7 & 11 & 24 & 12 & 19 & 2 & 2 \\
\hline Adolescent & 8 & 18 & 15 & 11 & 12 & 13 & 1 & 0 \\
\hline Adult & 12 & 48 & 31 & 29 & 27 & 21 & 10 & 2 \\
\hline Total & 48 & 73 & 57 & 64 & 51 & 53 & 13 & 4 \\
\hline p-Value & \multicolumn{2}{|c|}{$0.01 *$} & \multicolumn{2}{|c|}{0.77} & \multicolumn{4}{|c|}{0.15} \\
\hline
\end{tabular}

Table 4. Occurrence of tooth fractures and luxation injuries in permanent and deciduous teeth

\begin{tabular}{|c|c|c|c|c|c|}
\hline \multirow{2}{*}{ Diagnosis } & \multicolumn{2}{|c|}{ Permanent } & \multicolumn{2}{|c|}{ Deciduous } & \multirow{2}{*}{ Total } \\
\hline & Anterior & Posterior & Anterior & Posterior & \\
\hline \multicolumn{6}{|l|}{ Fractures } \\
\hline Infarction & 12 & 0 & 0 & 0 & $12(7.8 \%)$ \\
\hline Enamel & 16 & 3 & 1 & 0 & $17(11.11 \%)$ \\
\hline Enamel-dentin & 51 & 15 & 2 & 0 & $68(44.44 \%)$ \\
\hline Enamel-dentin-pulp & 11 & 2 & 1 & 0 & $14(9.1 \%)$ \\
\hline Crown-root & 5 & 1 & 2 & 0 & $8(5.2 \%)$ \\
\hline Crown-root-pulp & 15 & 1 & 0 & 0 & $16(10.4 \%)$ \\
\hline Cervical root & 4 & 0 & 0 & 0 & $4(2.6 \%)$ \\
\hline Middle root & 7 & 0 & 0 & 0 & $7(4.57 \%)$ \\
\hline Apical root & 7 & 0 & 0 & 0 & $7(4.57 \%)$ \\
\hline Total & 125 & 22 & 6 & 0 & 153 (100\%) \\
\hline \multicolumn{6}{|l|}{ Luxation } \\
\hline Concussion & 18 & 0 & 2 & 0 & $20(17.85 \%)$ \\
\hline Subluxation & 17 & 0 & 14 & 0 & $31(27.67 \%)$ \\
\hline Lateral luxation & 14 & 0 & 10 & 0 & $24(21.42 \%)$ \\
\hline Intrusion & 1 & 0 & 7 & 0 & $8(7.14 \%)$ \\
\hline Extrusion & 1 & 0 & 6 & 0 & 7 (6.25\%) \\
\hline Avulsion & 17 & 0 & 5 & 0 & $22(19.64 \%)$ \\
\hline Total & 68 & 0 & 44 & 0 & 112 (100\%) \\
\hline
\end{tabular}

Table 5. Occurrence of TDIs with respect to overjet

\begin{tabular}{|c|c|c|c|c|c|c|c|c|}
\hline \multirow{2}{*}{ Overjet } & \multicolumn{2}{|c|}{ Tooth fracture } & \multicolumn{2}{|c|}{ Luxation injury } & \multicolumn{4}{|c|}{ Soft Tissue/Bony injury } \\
\hline & None & Present & None & Present & None & Soft & Bony & Both \\
\hline$\leq 3 \mathrm{~mm}$ & 39 & 55 & 46 & 48 & 41 & 41 & 9 & 3 \\
\hline$>3 \mathrm{~mm}$ & 3 & 12 & 8 & 7 & 8 & 5 & 2 & 0 \\
\hline NA* & 6 & 6 & 3 & 9 & 2 & 7 & 2 & 1 \\
\hline Total & 48 & 73 & 57 & 64 & 51 & 53 & 13 & 4 \\
\hline p-Value & \multicolumn{2}{|c|}{0.19} & \multicolumn{2}{|c|}{0.24} & \multicolumn{4}{|c|}{0.42} \\
\hline
\end{tabular}

*NA: Not applicable- could not be assessed because of missing, extruded, intruded or avulsed anterior teeth

fractures $(p=0.19)$, Iuxation injuries $(p=0.24)$, soft tissue injuries and bony injuries $(\rho=0.42)$. However in patients having more than $3 \mathrm{~mm}$ overjet; the occurrence of tooth fracture was higher. Similarly, there was no significant difference in association between lip competency and TDI (Table 5).

\section{DISCUSSION}

The present study showed that males had greater risk for TDls, which is in agreement with other studies. ${ }^{4-11}$ Higher prevalence in males can be attributed to their active involvement in sports, outdoor activities and violent 
behavior. Among various causes, fall and RTA were more common as found in other studies. ${ }^{4-11}$ Females were more prone to TDIs because of RTA and most of them sustained Iuxation injuries compared to male counterparts. Adhikari et al. showed that, females sustained TDls owing to falls and males due to RTA. ${ }^{11}$

Children were more prone to injuries due to fall and adults to RTA. Children during the development of milestones learnto walk and involve actively in sports; are prone to fall and adults generally involve in outdoor activities could the reasons for these occurrences. The adults sustained more tooth injuries than children, which was statistically significant $(p<0.01)$, and children had more luxation injuries. It could be due to higher elasticity of the bone in children that has the ability to absorb more energy of impact favoring luxation injuries. Secondly, smaller crown and roots favor dislocation rather than fractures. ${ }^{12}$

Soft tissue injuries are usually not recorded in other studies and this study has shown that $43.8 \%$ and $10.7 \%$ had soft tissue and bony injuries respectively. Though Ekanayake's ${ }^{8}$ study showed lower prevalence of $14 \%$, Skaricic et $a l^{13}$ and Vuletic et $a^{1 / 4}$ has shown higher prevalence of soft tissue injuries (45.4\%and $55.5 . \%$ respectively) in children. Therefore, these parameters must be given equal importance in TDIs. Previous studies done in Nepal and outside have shown that $\mathrm{MCl}$ followed by $\mathrm{MLI}$ in both permanent and deciduous dentition are the most commonly affected tooth by TDIs. ${ }^{10,11}$ This is because of the position and protrusion of the maxillary incisors in the oral cavity, they are more prone to TDIs and this study has shown that mostly permanent and deciduous $\mathrm{MCl}$ and MLI sustained tooth fractures and luxation injuries. Previous studies have shown the pattern on injuries in anterior teeth only. Here, $14.9 \%$ of the total fractured permanent teeth were posteriors, which are often overlooked. More studies must be conducted to assess the prevalence of injury in posterior teeth as well. In this study, it was observed that enamel-dentin fracture and subluxation were the most common type of TDls. The result resembled other studies done in Brazil, Denmark, Turkey and Nigeria. 6,7,15,16 In context to Nepal, incidence of complicated tooth fractures and avulsions were more. ${ }^{10,11}$ Minor injuries, though common, maybe underrated because patients with minimal complaint may not report to the hospital or may go unnoticed.

A systematic review of Nguyen et al concluded that children with overjet more than $3 \mathrm{~mm}$ are approximately two times at greater risk of TDls in anterior teeth. ${ }^{17}$ Similarly, a meta-analysis concluded that large overjet may double or triple the risk for TDI to anterior teeth. ${ }^{18} \mathrm{~A}$ study concluded that an increased overjet and anterior openbite is associated with TDIs only when inadequate lip coverage is also present because lips can partly absorb the impact of trauma. ${ }^{19}$ Koroluk et al suggested that orthodontic intervention aimed at reducing trauma should begin early, though the injuries tended to be minor, and the expected treatment cost of traumatized incisor was small compared to expected additional cost of orthodontic intervention. ${ }^{20}$ In our study, there was no significant difference in the occurrence of tooth fractures and luxation injuries in the groups with overjet $\leq 3 \mathrm{~mm}$ and overjet $>3 \mathrm{~mm}$, though there was higher incidence of tooth fractures in second group. Likewise, there was no significant difference in occurrence of TDIs in patients with competent and incompetent lips.

Our study showed that Angle's Class II, Class III showed higher incidence of TDIs. In India, maximum TDIs were seen in children having Angle Class II Div 1 molar relationship and/or overjet greater than $5.5 \mathrm{~mm} .{ }^{21}$ Kramer et al demonstrated that more than twofold greater probability of TDI among adolescents with an abnormal molar relationship and the effect remained even after controlling the overjet, demonstrating an independent effect of this malocclusion in the antero-posterior direction. ${ }^{22}$ Therefore, rather than cross-sectional studies, longitudinal study is essential to observe the effect of orthodontic treatment on reducing risk of TDIs.

Due to the cross-sectional nature of this study, temporal relationship of the cause and effect could not be shown. The results of this study must be interpreted within the limitations of this study and further cohort studies including larger samples must be done. Such study should include other associated parameters like environmental factors, human behavior, illness (epilepsy, cerebral palsy), physical limitations, learning difficulties, abuse, etc. Additionally, it is necessary to assess treatment seeking behavior, treatment needs, financial burden and QoL in patients with TDIs.

\section{CONCLUSION}

TDIs are common in males and falls and RTA being common cause. Children are prone to sustain luxation injuries due to fall, while adults show more tooth fractures due to RTA. Enamel-dentin fractures and subluxation injuries are common and $\mathrm{MCl}$ are most frequently affected. Trauma to soft tissue and posterior teeth are common and must not be overlooked. Though no association is observed between occurrence of TDIs and malocclusion, overjet and lip competency, higher incidence are seen in patients with Class II and overjet $>3 \mathrm{~mm}$.

OJN 


\section{REFERENCES}

1. Bae JH, Kim YK, Choi YH. Clinical characteristics of dental emergencies and prevalence of dental trauma at a university hospita emergency center in Korea. Dent Traumatol. 2011;27(5):374-8.

2. JO A, Andreason F. Textbook and color atlas of traumatic injuries. 3rd ed. Copenhagen: Munksgaard; 1994.

3. Tsukiboshi M. Treatment Planning for Traumatized Teeth. In: Quintessence Publishing Co, Inc. 2000. p. 9-15.

4. Bücher K, Neumann C, Hickel R, Kühnisch J. Traumatic dental injuries at a German University Clinic 2004-2008. Dent Traumatol. 2013;29(2):127-33.

5. Lam R, Abbott P, Lloyd C, Lloyd C, Kruger E, Tennant M. Dental trauma in an Australian rural centre. Dent Traumatol. 2008;24(6):663-70.

6. Borin-Moura L, Azambuja-Carvalho P, Daer-de-Faria G, Barros-Gonçalves L, Kirst-Post L, Braga-Xavier C. A 10-year retrospective study of dental trauma in permanent dentition. Rev Esp Cir Oral y Maxilofac. 2016;20:1-6.

7. Lauridsen E, Hermann NV, Gerds TA, Kreiborg S, Andreasen JO. Pattern of traumatic dental injuries in the permanent dentition among children, adolescents, and adults. Dent Traumatol. 2012;28(5):358-63.

8. Ekanayake L, Perera M. Pattern of traumatic dental injuries in children attending the University Dental Hospital, Sri Lanka. Dent Traumatol. 2008;24(4):471-4.

9. Gulinelli JL, Saito CTMH, Garcia-Júnior IR, Panzarini SR, Poi WR, Sonoda CK. Occurrence of tooth injuries in patients treated in hospital environment in the region of Araçatuba, Brazil during a 6-year period. Dent Traumatol. 2008;24(6):640-4.

10. Dikshit P, Limbu S, Bhattarai R. Distribution of Dental Trauma to Anterior Teeth among Children visiting Kantipur Dental College, Kathmandu, Nepal. Int J Sci Res. 2017;(5):44-6.

11. Adhikari R, Gurung M. Anterior Traumatic Dental Injuries amongst Children and Adolescents in Western Region of Nepal. Am J Public Heal Res [Internet]. 2015;3(4A):62-4. Available from: http://pubs.sciepub.com/ajphr/3/4A/13/index.html

12. Noori AJ, Al-Obaidi WA. Traumatic dental injuries among primary school children in Sulaimani city, Iraq. Dent Traumatol. 2009;25(4):442-6.

13. Škaričić J. Prevalence, Type and Etiology of Dental and Soft Tissue Injuries in Children in Croatia. Acta Clin Croat [Internet]. 2016 ;209-15. Available from: http://hrcak.srce.hr/index.php?show=clanak\&id_clanak_jezik=242947

14. Vuletić M, Škaričić J, Batinjan G, Trampuš Z, Bagić IČ, Jurić H. A retrospective study on traumatic dental and soft- tissue injuries in preschool children in Zagreb, Croatia. Bosn J Basic Med Sci. 2014;14(1):12-5.

15. Atabek D, Alaçam A, Aydintuğ I, Konakoğlu G. A retrospective study of traumatic dental injuries. Dent Traumatol. 2014;30(2):154-61.

16. Ajayi DM A-SI, Sulaiman AO EE. A retrospective study of traumatic injuries to teeth at a Nigerian tertiary hospital. Niger J Clin Pr. 2012;15(3):320-5.

17. Nguyen Q V, Bezemer PD, Habets L, Prahl-Andersen B. A systematic review of the relationship between overjet size and traumatic dental injuries. Eur J Orthod [Internet]. 1999;21 (5):503-15. Available from: http://dx.doi.org/

18. Elkhadem A. Large overjet may double the risk of dental trauma. Vol. 16, Evidence-Based Dentistry. 2015. p. 56.

19. Bonini GC, Bönecker M, Braga MM, Mendes FM. Combined effect of anterior malocclusion and inadequate lip coverage on dental trauma in primary teeth. Dent Traumatol. 2012;28(6):437-40.

20. Koroluk LD, Tulloch JF, Phillips C. Incisor trauma and early treatment for Class II Division 1 malocclusion. Am J Orthod Dentofacial Orthop [Internet]. 2003;123(2):1 16-7. Available from: http://onlinelibrary.wiley.com/o/cochrane/clcentral/articles/323/CN-00413323/frame.html

21. Patel M, Sujan S. The prevalence of traumatic dental injuries to permanent anterior teeth and its relation with predisposing risk factors among 8-13 years school children of Vadodara city: An epidemiological study. J Indian Soc Pedod Prev Dent [Internet]. 2012;30(2):151. Available from: http://www.jisppd.com/text.asp?2012/30/2/151/99992

22. Kramer PF, Pereira LM, llha MC, Borges TS, Freitas MPM, Feldens CA. Exploring the impact of malocclusion and dentofacial anomalies on the occurrence of traumatic dental injuries in adolescents. Angle Orthod. 2017;87(6):816-23. 